Dawid Mielnik ${ }^{1}$

\title{
Filozoficzna apologia monofizytyzmu w Rozjemcy Jana Gramatyka
}

\section{Wprowadzenie}

W starożytności chrześcijańskiej spory dotyczące relacji względem siebie Ojca, Syna i Ducha Świętego, Ich statusu ontycznego czy relacji natur drugiej osoby Trójcy Świętej były bardzo napięte i prowadziły do zaostrzonych sporów ${ }^{2}$. Warto jednak mieć świadomość tego, że powstające na gruncie owych sporów podziały nie zawsze wynikały z faktycznych różnic, ale mogły być spowodowane stosowaniem różnej terminologii wobec tych samych pojęć ${ }^{3}$. Do żywszych dyskusji z pewnością można zaliczyć kontrowersję związaną z próbą określenia ilości natur w Synu Bożym. Wielkie umysły ówczesnego świata zabierały głos w tej sprawie i starały się uzasadniać swoje własne stanowiska. Problem teoretycznie został zamknięty w 451 roku na czwartym

1 Dr Dawid Mielnik, doktorant i student na Katolickim Uniwersytecie Lubelskim Jana Pawła II, redaktor czasopisma „Vox Patrum”; e-mail: mielnikdawid@gmail.com; ORCID: 0000-0002-2701-4889.

2 Trzeba pamiętać, że współcześnie, dzięki szerszemu dostępowi do źródeł starożytnych i bardziej szczegółowym badaniom, poglądy teologiczne wielu starożytnych myślicieli są lepiej znane, co pozwala niekiedy na „rehabilitację” ortodoksji niektórych osób. Dotyczy to również Nestoriusza, któremu przypisuje się autorstwo jednej z bardziej znanych herezji, a którego nauczanie ostatnimi czasy jest ponownie rewidowane. Zob. R. Kosiński, Dzieje Nestoriusza, biskupa konstantynopola w latach 428-431, „Studia Źródłoznawcze" 7 (2008) s. 30-31.

3 Zob. P. Sielużycki, Chrystologia Nestoriusza $w$ rozwoju badań ubiegłego wie$k u$, „Salvatoris Mater” 3/4 (2001) s. 151-158; S. Bralewski, Sobór w Chalcedonie w polityce wewnętrznej cesarza Marcjana, „Acta Universitatis Lodziensis. Folia Historica” 44 (1992) s. 72. 
soborze powszechnym ogłoszeniem ugody chalcedońskiej, niemniej nawet sto lat później zdarzali się myśliciele kwestionujący postanowienia soborowe. Jednym z nich był chrześcijański filozof Jan Gramatyk, znany również jako Filopon. Solidnie wykształcony Aleksandryjczyk podjął się dosyć kontrowersyjnej próby obrony stanowiska odrzuconego przez zgromadzonych na soborze ojców, a więc doktryny monofizyckiej. Postać tego filozofa jest jednak o tyle ważna, że próbował on uzasadnić monofizytyzm nie w oparciu o źródła objawione, ale o namysł filozoficzny, co czyni jego wykład niezwykle ciekawy i zasługujący na uważniejszą analizę.

Celem niniejszego opracowania będzie próba przedstawienia filozoficznej argumentacji wykorzystanej przez Filopona dla obrony doktryny monofizyckiej. Osiągnięcie celu pracy będzie możliwe dzięki analizie argumentów wykorzystanych przez Jana Gramatyka. Materiałem źródłowym pracy będzie najważniejsze dzieło filozofa poświęcone tej problematyce, a więc Rozjemca ${ }^{4}$. Opracowanie zostanie usystematyzowane w trzech głównych częściach. Najpierw będzie miała miejsce krótka prezentacja wspomnianego utworu Filopona. W części drugiej W sposób systematyczny zostanie przedstawiona argumentacja obecna w Rozjemcy. Wreszcie w części trzeciej zostaną podane najważniejsze cechy argumentacji Jana Gramatyka na rzecz doktryny monofizyckiej.

\section{Charakterystyka dziela Filopona}

Powstałego krótko przed II soborem konstantynopolitańskim Rozjemce, zwanego również niekiedy Arbitrem ${ }^{5}$, można zaliczyć do najważniejszych pism teologicznych chrześcijańskiego myśliciela ${ }^{6}$. Posiada ono zdecydo-

4 Zob. Ch. Wildberg, Philoponus, w: Routledge Encyclopedia of Philosophy, red. E. Craig, London 1998, s. 375; R. Sorabji, Philoponus John, w: The Oxford Classical Dictionary, red. S. Hornblower - A. Spawforth, Oxford 2012, s. 1135; B. Merry, Encyclopedia of Modern Greek Literature, London 2004, s. 56.

5 W języku greckim utwór ten nosi tytuł Diaitētēs, na gruncie literatury anglojęzycznej natomiast funkcjonuje pod określeniem Arbiter, czasem Arbitrator. Por. Philoponus, On Aristotle Physics 3, ed. M.J. Edwards, New Delhi 1994, s. 189. Nie zostało jeszcze dokonane tłumaczenie dzieła filozofa na język polski. Podstawą dla analiz zawartych w niniejszym opracowaniu było wydanie zawarte w: John Philoponus, Arbiter, w: John Philoponus and the Controversies over Chalcedon in the Sixth Century: A Study and Translation of the Arbiter, ed. U.M. Lang, Leuven 2001, s. 173-217.

6 Zob. U.M. Lang, Nicetas Chroniates, a Neglected Witness to the Greek Text of John Philoponus' Arbiter, JOTS 48/2 (1997) s. 540; Y. Shayegan, The transmission 
wanie promonofizycki oraz antychalcedoński charakter ${ }^{7}$. Zapewne z tego powodu stało się ono przedmiotem ostrego ataku ze strony niektórych teologów prochalcedońskich ${ }^{8}$. Chociaż oryginalnie to ważne dzieło Filopona zostało napisane, tak jak pozostałe jego pisma, w języku greckim, to jednak do dzisiejszych czasów w tym języku przetrwało jedynie w niewielkich fragmentach. Zasadniczą bazę dla odtworzenia zawartej w Rozjemcy argumentacji Jana Gramatyka stanowi przekład syryjski, który z oczywistych względów pozbawia czytelnika możliwości weryfikacji oryginalnych słów użytych przez autora w prowadzonej przez niego polemice 9 . Jest to o tyle istotny mankament, że chrystologiczne spory z pierwszych wieków istnienia Kościoła nierzadko dotyczyły właśnie wykorzystywanych słów i ich określonego zakresu znaczeniowego.

Sam autor podzielił swój traktat na dziesięć różnej wielkości rozdziałów, przy czym granice poszczególnych rozdziałów zostały dość wyraźnie zaznaczone przez filozofa ${ }^{10}$. Z punktu widzenia treści utworu zasadne wydaje się ustrukturyzowanie dzieła Filopona w pięciu głównych częściach. Traktat otwiera prolog, w którym autor podaje cel pisanego przez siebie dzieła - jest nim próba rozwiązania chrystologicznego problemu dotyczącego relacji natur w Chrystusie, a zwłaszcza sporu dotyczącego ich ilości po akcie zjednoczenia Logosu z ludzką naturą. Wstęp traktatu zasługuje zresztą na szczególną uwagę pod kątem zawartej w niej świadomości metodologicznej autora oraz wykazania się przez niego dobrym rozumieniem prowadzonych przez chrześcijan sporów chrystologicznych. Co więcej, część ta zawiera swoistego rodzaju wprowadzenie do traktatu na poziomie wstępnych rozważań relacji Logosu i ludzkiego ciała.

Drugą część traktatu stanowi cykl rozdziałów od pierwszego do szóstego. W tej części dzieła Jan Gramatyk podaje systematyczny wykład przyjmowanego przez siebie rozwiązania, a więc doktryny monofizyckiej ${ }^{11}$.

of Greek philosophy to the Islamic world, w: History of Islamic Philosophy, red. S.H. Nasr - O. Leaman, London 1996, s. 95. Por. jednak: P. Cumin, Christ at the Crux: The Mediation of God and Creation in Christological Perspective, Eugene 2014, s. 56.

7 Zob. E.J. Watts, City and School in Late Antique Athens and Alexandria, Berkeley 2006, s. 249.

8 Por. A. Rigolio, Christians in Conversation: A Guide to Late Antique Dialogues in Greek and Syriac, Oxford 2019, s. 231; A. Grillmeier - T. Hainthaler, Christ in Christian Tradition, t. 2, Oxford 2013, s. 278.

9 Zob. J.C. Plott, Global History of Philosophy, t. 3, Delhi 1980, s. 500.

10 Por. J.E. McKenna, The Setting in Life for The Arbiter of John Philoponos, Sixth Century Alexandrian Scientist, Eugene 1997, s. 21.

11 Zob. U.M. Lang, John Philoponus and the Controversies over Chalcedon in the Sixth Century: A Study and Translation of the Arbiter, Leuven 2001, s. 41. 
Zasadniczo każdy rozdział poświęcony został oddzielnemu argumentowi na rzecz uznawanej tezy, przy czym należy podkreślić ścisłą łączność poszczególnych argumentacji i ich wzajemną komplementarność ${ }^{12}$. Na trzecią część traktatu Filopona składają się rozdziały od siódmego do dziewiątego. Właściwym celem tego etapu prowadzonych przez autora analiz jest próba odparcia stanowiska przyjętego na soborze chalcedońskim, a więc rozwiązania, według którego w jednej hipostazie Syna Bożego zostały zjednoczone dwie różne natury nie na podstawie ich złączenia przez naturę, ale przez hipostazę. Część ta ma zatem charakter ściśle polemiczny. Czwartą część traktatu stanowi rodzaj dość rozbudowanego apendyksu, w którym filozof mierzy się z zarzutami stawianymi wyznawanej przez niego doktrynie monofizyckiej. Wreszcie dzieło wieńczy krótkie podsumowanie ${ }^{13}$.

\section{Schemat argumentacji Jana Gramatyka}

Jak już zostało zauważone na wcześniejszym etapie analiz, zasadniczo w drugiej części traktatu podzielonej przez filozofa na sześć rozdziałów Filopon teoretycznie podaje sześć niezależnych argumentów mających przemawiać za doktryną monofizycką. W tym kontekście warto jednak zwrócić uwagę na dwie kwestie. Po pierwsze, należy podkreślić dość wyraźną dysproporcję objętościową pomiędzy poszczególnymi rozdziałami. Ostatnie rozdziały pierwszej części traktatu są wyraźne krótsze od poprzednich. Po drugie, argumenty stosowane przez Jana Gramatyka w mniejszym bądź większym stopniu pokrywają się, a założenia kolejnych bardzo wyraźnie bazują na tym, co chrześcijański myśliciel napisał poprzednio. W związku z tym kolejne argumenty można niekiedy rozumieć jako rozwinięcie już poprzednio wyrażonych myśli.

W świetle przeprowadzonej analizy zasadne wydaje się zatem dokonanie pewnych połączeń i sprowadzenie sześciu rozdziałów do reprezentatywnych argumentacji Filopona. Dwoma wyraźnie wiodącymi argumentami filozofa są te, które zostały sformułowane w dwóch pierwszych rozdziałach, kolejne natomiast w jakiś sposób opierają się na założeniach wynikających właśnie $\mathrm{z}$ tych dwóch passusów traktatu ${ }^{14}$. W świetle tych

12 Ten problem zostanie nieco rozwinięty na dalszym etapie analiz.

13 Z punktu widzenia obranego celu badawczego autora niniejszego opracowania będzie interesować przede wszystkim druga część traktatu Filopona, gdyż tam zawarta została systematyczna prezentacja oraz uzasadnienie doktryny monofizyckiej.

$14 \mathrm{Z}$ drugiej strony należy być świadomym tego, że również te dwie pierwsze argumentacje w jakiś sposób pokrywają się. 
ustaleń w niniejszej części zostaną zaprezentowane dwa argumenty Jana Gramatyka z dwóch pierwszych rozdziałów traktatu, które następnie zostaną rozwinięte o jego dowodzenia $z$ kolejnych rozdziałów traktatu ${ }^{15}$.

Rozdział pierwszy poświęcony został próbie wykazania zasadności monofizytyzmu przez pokazanie adekwatności bądź nie nazwy "Chrystus” odnoszonej do jednej zmieszanej lub dwóch różnych natur wcielonego Logosu. Filopon rozpoczyna całą argumentację od postawienia tezy, że koniecznym warunkiem zjednoczenia dwóch odrębnych natur jest powstanie $\mathrm{w}$ wyniku tego procesu jednego bytu ${ }^{16}$. Jednocześnie filozof pokazuje niezasadność opowiedzenia się za innym rozwiązaniem. Jego zdaniem gdyby końcowym efektem zjednoczenia natur nie było powstanie jednego bytu, w takim przypadku zasadne byłoby podważenie faktu zjednoczenia, co w przypadku Syna Bożego nie może mieć miejsca. Za autentycznością zjednoczenia nie przemawia jednak przyjęcie przez Logos jedynie właściwości przyjmowanej natury na wzór ciała przyjmującego właściwości ciepła, ale faktycznie stanie się czymś jednym z jednoczoną rzeczą. W tym przypadku przyjęcie właściwości tej rzeczy oczywiście ma miejsce, niemniej jest tylko jednym $z$ elementów, i to wcale nie najważniejszym, tego zjednoczenia ${ }^{17}$.

Wychodząc od analizy samego procesu i przechodząc na jego efekt końcowy, Filopon zauważa, że o rezultacie dokonanego zjednoczenia można mówić na dwóch płaszczyznach: albo na poziomie nazwy, albo na poziomie natury. Opowiedzenie się za pierwszym rozwiązaniem w zasadzie nie dopuszcza zdaniem filozofa możliwości przyjęcia realności dokonanego zjednoczenia, gdyż ono, pozostając jedynie na poziomie nazwy, nie jest rzeczywiste ${ }^{18}$. Ponieważ w przypadku Jezusa chrześcijanie wierzą w realność zjednoczenia natur, pozostaje im jedynie możliwość opowiedzenia się za drugą ewentualnością. W takim przypadku chrześcijański myśliciel do-

15 Warto zauważyć, że i inni autorzy nie traktują poszczególnych rozdziałów tej części Rozjemcy jako odrębnych argumentacji. Tak czyni choćby Lang, który wyróżnia jedynie pięć argumentów zamiast spodziewanych sześciu.

16 Zob. Joannes Philoponus, Arbiter sive de unione 7, Lang, s. 178. Por. Lang, John Philoponus and the Controversies over Chalcedon, s. 48.

17 Zob. Joannes Philoponus, Arbiter sive de unione 7, Lang, s. 179.

18 Zob. Joannes Philoponus, Arbiter sive de unione 8, Lang, s. 179. Odwołując się do współczesnego kontekstu, można zilustrować tę myśl Filopona choćby sposobem stosowania określenia „Bóg” wobec Jezusa w nauczaniu świadków Jehowy czy Ariusza. Dla przedstawicieli tych nurtów termin „Bóg” odniesiony do Syna Bożego przyjmuje inne znaczenie niż odniesiony do Jego Ojca. O ile w przypadku Ojca słowo to wskazuje na prawdziwe bóstwo osoby, której dotyczy, o tyle w przypadku Jezusa określa jedynie pewne właściwości ,podobne” do tych, które posiada Ojciec. 
puszcza możliwość opowiedzenia się za dwoma rozwiązaniami. Pierwszym z nich jest przyjęcie zjednoczenia na płaszczyźnie przypadłości, drugim natomiast przyjęcie zjednoczenia na płaszczyźnie substancji ${ }^{19}$. Pierwszą ewentualność filozof odrzuca, ponieważ jego zdaniem w przypadku zjednoczenia tylko na poziomie przypadłości niezasadne jest mówienie o realnym zjednoczeniu. Jeżeli zaś następuje zjednoczenie substancji, za czym chrześcijanie się opowiadają, które jest jedynym możliwym do przyjęcia wyjaśnieniem zjednoczenia natur w Chrystusie, to według Filopona rezultatem tego procesu musi być powstanie jednej złożonej natury ${ }^{20}$.

Po tych rozważaniach chrześcijański myśliciel podejmuje temat desygnatów, na które wskazuje nazwa „Chrystus”21. W świetle dotychczasowych rozważań Filopon próbował pokazać, że jedynym możliwym do zaakceptowania przez chrześcijan rozwiązaniem jest opowiedzenie się za zjednoczeniem natur w Synu Bożym na poziomie substancji. W związku z tym, że Jezus ma naturę ludzką i boską, to konsekwentnie określenie „Chrystus” może być rozumiane dwojako. Pierwszą ewentualnością jest odnoszenie go do jednej natury, drugą natomiast jest nazywanie nim obu natur ${ }^{22}$. W zakresie tej drugiej możliwości Filopon dopuszcza jeszcze dwa inne rozwiązania. Wspomniane określenie może być odnoszone albo do każdej natury oddzielnie, albo do obu, ale ujętych razem. W przypadku przyjęcia takiego rozwiązania, że określenie „Chrystus” przysługuje każdej naturze oddzielnie, należałoby przyjąć istnienie dwóch Chrystusów uczestniczących w jednym imieniu, lecz różniących się naturą, co jest dla chrześcijan nie do przyjęcia ${ }^{23}$. Druga ewentualność, to znaczy taka, gdzie kluczowe określenie jest odnoszone do obu natur, ale ujętych razem, również według starożytnego myśliciela jest problematyczna. Jednoczesne ujęcie natur broni co prawda tożsamości co do natury, ale powoduje odrębność numeryczną, gdyż wskazuje na różnych przedstawicieli tego samego gatunku ${ }^{24}$. W konsekwencji zatem i tak to rozwiązanie zmusza do przyjęcia istnienia dwóch Chrystusów, a zatem stawia chrześcijan

19 Zob. Joannes Philoponus, Arbiter sive de unione 8, Lang, s. 179-180.

20 Zob. Joannes Philoponus, Arbiter sive de unione 8, Lang, s. 180.

21 Zob. Nicetae Choniatae ex libro IX thesauri orthodoxae fidei, PG 140, 56.

22 Zob. Joannes Philoponus, Arbiter sive de unione 9, Lang, s. 180-181.

23 Zob. Joannes Philoponus, Arbiter sive de unione 9, Lang, s. 181. Przykładem na gruncie języka polskiego ilustrującym tok rozumowania Filopona jest choćby nazwa kot, która może się odnosić albo do zwierzęcia domowego, albo do studenta pierwszego roku. Choć obydwaj przedstawiciele dzielą tą samą nazwę, to jednak posiadają zupełnie inne natury, co ostatecznie przekłada się na to, że są to dwa zupełnie różne byty.

24 Zob. Joannes Philoponus, Arbiter sive de unione 9, Lang, s. 181. Sam filozof przywołuje przykład Piotra i Pawła. Obydwaj posiadają tę samą naturę (człowiek), co sprawia, 
w takiej samej sytuacji jak poprzednie rozwiązanie. W związku z tym jedynym możliwym rozwiązaniem jest odniesienie określenia „Chrystus” tylko do jednej natury ${ }^{25}$.

Ta myśl zostaje rozwinięta przez filozofa na dalszym etapie prowadzonych analiz w rozdziale trzecim swojego traktatu. Jan Gramatyk zauważa, że nazwa wskazuje na konkretną naturę nawet w przypadku, gdy jest możliwe poświadczenie większej ilości egzemplarzy posiadających daną naturę. Dla przykładu, określenie „koń” przysługuje wszystkim przedstawicielom tego gatunku. Kiedy jednak ktoś stosuje tę nazwę w odniesieniu do ściśle określonego konia, a więc wybranego przedstawiciela całego gatunku, wskazuje on na naturę zindywidualizowaną właśnie w tej konkretnej jednostce ${ }^{26}$. Istotą tych rozważań jest próba dostarczenia dodatkowego argumentu za tym, że w każdym przypadku nazwa odnosi do jednej natury, a zatem zwolennicy unii hipostatycznej konsekwentnie musieliby uznać istnienie dwóch różnych Chrystusów.

Czwarty rozdział traktatu Filopona ${ }^{27}$ jest $\mathrm{w}$ zasadzie bezpośrednią kontynuacją myśli filozofa zawartych w części poprzedzającej. Istotą tego fragmentu utworu Jana Gramatyka jest dostarczenie kolejnych przykładów mających obrazować słuszność rozumowania proponowaną przez starożytnego myśliciela. Filopon odwołuje się do dwóch istotnych przykładów. Pierwszym z nich jest obraz relacji pomiędzy ideą statku a jego konkretyzacją, drugim natomiast jest obraz zjednoczonych $\mathrm{w}$ ciele członków ${ }^{28}$. W pierwszym z przywołanych przykładów filozof kreśli obraz konstruktora okrętów. Jan Gramatyk stwierdza, że jeszcze przed wyprodukowaniem jakiegokolwiek okrętu w umyśle danego konstruktora istnieje ściśle określony projekt statku, a więc jego forma, który następnie zostaje uzewnętrzniony i skonkretyzowany w konkretnym egzemplarzu ${ }^{29}$. Zauważa on dalej, że jedna i ta sama forma statku $\mathrm{z}$ umysłu konstruktora może zostać skonkretyzowana nie tylko w jednym egzemplarzu, ale w kilku. W takim przypadku jedna natura, choć konkretyzuje się w kilku egzemplarzach, to jednak w każdym $\mathrm{z}$ nich istnieje w sposób całkowity ${ }^{30}$. W tym kontekście

że to samo określenie (człowiek) przysługuje każdemu z nich, ale ze względu na różnicę ilościową są odrębnymi bytami.

25 Zob. Lang, John Philoponus and the Controversies over Chalcedon, s. 51.

26 Dla zrozumienia myśli Filopona istotna jest znajomość podziału na naturę pojedynczą i wspólną, który został wprowadzony na dalszych stronnicach traktatu wychodzących poza zakres tematyczny niniejszego opracowania.

27 Zob. Nicetae Choniatae ex libro IX thesauri orthodoxae fidei, PG 140, 57.

28 Zob. Joannes Philoponus, Arbiter sive de unione 16, Lang, s. 187.

29 Zob. Lang, John Philoponus and the Controversies over Chalcedon, s. 56.

30 Zob. Joannes Philoponus, Arbiter sive de unione 16, Lang, s. 187. 
zdaniem Jana Gramatyka na zasadzie analogii konsekwentnie należałoby przyjąć, że, skoro Chrystus miałby posiadać dwie natury, jak tego chcą zwolennicy dogmatu chalcedońskiego, to również w sposób konieczny egzemplifikowałby się $\mathrm{w}$ dwóch różnych egzemplarzach (jednym czerpiącym swą tożsamość $\mathrm{z}$ natury boskiej $\mathrm{i}$ w drugim czerpiącym swą tożsamość z natury ludzkiej), co oczywiście jest nie do przyjęcia, jako że chrześcijanie wykluczają możliwość istnienia dwóch Chrystusów ${ }^{31}$.

Drugi z przywołanych przykładów związany jest z obrazem ciała i relacji poszczególnych członków względem całości. Filopon zauważa, że poszczególne części ciała, dzięki temu, że są zjednoczone, tworzą odrębną całość, jaką jest dany byt. Skomponowanie całości jest zatem możliwe przez to, że poszczególne członki nie są traktowane oddzielnie jako ręka, noga czy głowa ${ }^{32}$, ale jako ściśle złączone i skorelowane ze sobą elementy. Gdyby takie połączenie nie zaistniało, poszczególne członki byłyby podzielone. Ten obraz zostaje następnie odniesiony do Chrystusa. Jeżeli w Synu Bożym nie doszłoby do złączenia natur przez jedną zasadę złączenia, którą jest ukonstytuowanie się jednej tylko natury, to w takim przypadku nie można byłoby mówić o jedności Chrystusa, ale sam Syn Boży byłby podzielony na naturę boską i ludzką, co sprzeciwiałoby się uznawanej przez chrześcijan jedności ${ }^{33}$.

Te rozważania zostają uzupełnione w szóstym rozdziale traktatu filozofa, gdzie Jan Gramatyk podejmuje problem relacji pomiędzy definicją a jej desygnatem $^{34}$. Rozpoczynając swój wywód od pojęcia definicji, zauważa on, że definiowanie jakiegoś bytu polega na podaniu tego, co jest naturą danego bytu. W związku z tym powstała w wyniku definiowania definicja zawsze będzie wskazywać na pojedynczą naturę konkretnego bytu, ponieważ właśnie taką naturę on posiada ${ }^{35}$. Owo utożsamienie pozwala Filoponowi na przejście do kolejnego etapu argumentacji. Skoro każda definicja jest wskazaniem na pojedynczą naturę konkretnego bytu, to konsekwentnie adherenci rozwiązania soboru chalcedońskiego powinni przyjąć istnienie dwóch różnych definicji odnoszonych do Chrystusa ${ }^{36}$. W sposób konieczny wynika to z przyjęcia istnienia dwóch odrębnych natur w Synu Bożym ${ }^{37}$. Co więcej,

31 Zob. Joannes Philoponus, Arbiter sive de unione 17, Lang, s. 187-188; Lang, John Philoponus and the Controversies over Chalcedon, s. 58.

32 Takie odróżnianie jest oczywiście możliwe, ale jest to podział funkcyjny i czysto teoretyczny. Nie przekłada się on w żaden sposób na poziom ontologiczny.

33 Zob. Joannes Philoponus, Arbiter sive de unione 18, Lang, s. 188-189.

34 Zob. Nicetae Choniatae ex libro IX thesauri orthodoxae fidei, PG 140, 60.

35 Zob. Joannes Philoponus, Arbiter sive de unione 20, Lang, s. 189.

36 Zob. Lang, John Philoponus and the Controversies over Chalcedon, s. 59.

37 Zob. Joannes Philoponus, Arbiter sive de unione 20, Lang, s. 189-190. 
owe definicje, jako że odnosić się będą do dwóch różnych natur, nie będą wskazywać na ten sam desygnat, co z kolei zmuszałoby do zaakceptowania stanowiska niemożliwego do przyjęcia przez chrześcijan, że jest dwóch różnych Chrystusów.

Filozof podejmuje również przy tej okazji wątek dotyczący ewentualnej możliwości stosowania określenia „Chrystus” wobec Logosu jeszcze przed jego zjednoczeniem z ciałem. Jego zdaniem takie użycie wspomnianego słowa byłoby niepoprawne. Argumentując opowiedzenie się za takim rozwiązaniem, Filopon przywołuje przykład domu i materiałów użytych do jego stworzenia. Filozof zauważa, że poszczególnym materiałom (kamieniom, drewnu itd.) nie przysługuje określenie „dom” tak długo, dopóki nie zostaną one odpowiednio uporządkowane i nie zostanie im nadana odpowiednia forma ${ }^{38}$. Podobnie zatem słowo wskazujące na posiadającego jedną złożoną naturę Syna Bożego nie może być wobec Niego używane wtedy, kiedy nie wyraża ono zjednoczenia Logosu z naturą ludzką ${ }^{39}$.

Ostatnią odsłoną podejmowanej $\mathrm{w}$ ramach pierwszego rozdziału refleksji, pozostającej w ścisłym związku z dotychczasowymi badaniami, jest analiza określenia „Chrystus” odniesionego jednak nie do substancjalnego wymiaru Syna Bożego, ale do Jego strony akcydentalnej. Filopon, przytaczając opinie niektórych osób, zauważa, że kluczowe określenie może w pewnych przypadkach wskazywać na właściwości posiadane przez jaką́s substancję, a nie na samą substancję ${ }^{40}$. W tym kontekście może zatem wystąpić nieścisłość w zakresie stosowania danej nomenklatury względem Syna Bożego. Filozof uważa jednak, że nawet takie rozwiązanie nie musi wprowadzać żadnego zamieszania w jego dotychczasowe rozważania. Dzieje się tak dlatego, że nawet akcydentalne użycie danego terminu, oprócz wskazania na jakieś właściwości, może równocześnie odnosić się do samej substancji, czyli przyjmować znaczenie właściwe.

Rozdział drugi traktatu Jana Gramatyka poświęcony został przedstawieniu drugiej rozbudowanej argumentacji na rzecz monofizytyzmu. Po raz kolejny Filopon próbuje dowieść, że określenie „Chrystus” może być odnoszone tylko do pojedynczej natury Syna Bożego, a nie do dwóch odrębnych względem siebie natur. Argument ten jest zatem pochodną rozważań filozofa z poprzedniej części jego utworu. Swój schemat dowodze-

38 Zob. Lang, John Philoponus and the Controversies over Chalcedon, s. 49.

39 Zob. Joannes Philoponus, Arbiter sive de unione 14, Lang, s. 184-185.

40 Jako przykład Filopon przytacza dosłowne rozumienie greckiego terminu christos jako kogoś namaszczonego (olejem). Przy takiej interpretacji każda osoba posiadająca specjalną funkcję w Izraelu (kapłan, prorok, król) była „chrystusem” w tym sensie, że została naznaczona olejem podczas wymaganego obrzędu. Zob. Lang, John Philoponus and the Controversies over Chalcedon, s. 48-49. 
niowy rozpoczyna od pytania, czy po zjednoczeniu Logosu z ludzką naturą określenie „Chrystus” jest tożsame z tym, co jest wyrażane przez poszczególne natury Syna Bożego, czy też jest czymś odrębnym względem nich ${ }^{41}$. Filopon zauważa, że opowiedzenie się za drugim rozwiązaniem wprowadza istotny problem. Jeżeli jakiś byt istniałby jako ktoś inny od swojej własnej natury, byłby różny od samego siebie, co jest niemożliwe ${ }^{42}$. W oparciu o tę obserwację filozof stwierdza, że gdyby pod określeniem „Chrystus” rozumiano coś odrębnego od poszczególnych natur Syna Bożego, należałoby konsekwentnie przyjąć, że Chrystus jest kimś nietożsamym z samym sobą. Właściwym rozwiązaniem jest zatem przyjęcie, że po akcie zjednoczenia Logos jest tożsamy ze swoją własną naturą. W związku z tym Jan Gramatyk dostrzega istotny problem dla rozwiązania proponowanego przez zwolenników unii hipostatycznej. Skoro każdy byt jest tożsamy ze swoją własną naturą, a Chrystus miałby być złożony z dwóch natur, jak chcą adherenci dogmatu chalcedońskiego, w związku z tym konsekwentnie należałoby przyjąć, że są dwa Chrystusy: jeden tożsamy z naturą boską i drugi tożsamy z naturą ludzką, co oczywiście jest nie do przyjęcia przez chrześcijan ${ }^{43}$.

Swój tok rozumowania Filopon usiłuje zilustrować przez odwołanie się do obrazu słońca i posiadanych przez niego właściwości ${ }^{44}$. Nazywając to ciało niebieskie terminem ,słońce”, jednocześnie wskazuje się na naturę, którą posiada największe $\mathrm{z}$ ciał niebieskich ${ }^{45}$. O słońcu orzeka się właściwości, które ono posiada, a więc np. jasność, ciepło czy ruch po okręgu ${ }^{46}$. Starożytny myśliciel zauważa jednak, że z tego w żaden sposób nie wynika konieczność utożsamiania każdej wymienionej właściwości z odrębną naturą ${ }^{47}$. Mało tego, każdy z poszczególnych atrybutów słońca może być poświadczony w jakichś innych bytach ${ }^{48}$. Podobnie jest i z Chrystusem. Chociaż Syn Boży posiada właściwości natury ludzkiej, jak również atrybuty natury boskiej, to jednak są one pochodnymi jednego bytu konstytu-

41 Zob. Joannes Philoponus, Arbiter sive de unione 12, Lang, s. 183.

42 Jako zilustrowanie myśli filozofa przytoczyć można przykład człowieka, który z samej swojej natury jest istotą rozumną, co sprawia, że określenie „człowiek” jest z rozumnością związane w sposób nierozerwalny. Gdyby dany człowiek nie był bytem rozumnym, byłby kimś innym, niż jest, co pozostaje w sprzeczności z zasadą tożsamości.

43 Zob. Joannes Philoponus, Arbiter sive de unione 12, Lang, s. 183.

44 Zob. Nicetae Choniatae ex libro IX thesauri orthodoxae fidei, PG 140, 57.

45 Zob. Lang, John Philoponus and the Controversies over Chalcedon, s. 51.

46 Zob. Joannes Philoponus, Arbiter sive de unione 13, Lang, s. 183-184.

47 Zob. Joannes Philoponus, Arbiter sive de unione 13, Lang, s. 184.

48 Dla przykładu przysługujące słońcu jasność czy ciepło pojawiają się w ogniu, a ruch po okręgu - choćby w gwiazdach. 
owanego przez jedną ściśle określoną naturę posiadającą zbiór poszczególnych właściwości, które, rozpatrzone oddzielnie, przysługują Bogu i człowiekowi ${ }^{49}$.

\section{Główne cechy systematycznego dowodzenia doktryny monofizyckiej}

Przeprowadzone w poprzednich częściach opracowania analizy schematów argumentacji Jana Gramatyka ukazały ścisłą łączność poszczególnych argumentów wykorzystywanych przez filozofa. Mimo że sam Filopon dopatrywał się we własnym traktacie większej ilości odrębnych schematów argumentacji, za czym przemawia m.in. obecność w jego Rozjemcy kilku odrębnych rozdziałów, to jednak faktycznie poszczególne argumenty są od siebie zależne i zasadnicza baza dla całego systematycznego wywodu chrześcijańskiego myśliciela zawarta została w dwóch pierwszych argumentacjach. Za takim rozwiązaniem przemawia również pośrednio objętość poszczególnych rozdziałów analizowanego traktatu - najobszerniej przedstawione są właśnie pierwsze schematy argumentacji, podczas gdy pozostałe rozdziały są ewidentnie krótsze, ponieważ bazują na tym, co zostało przekazane wcześniej ${ }^{50}$. Taki sposób rozłożenia materiału pokazuje, że Filopon dążył do przeniesienia punktu ciężkości na początek wykorzystanej argumentacji, a dalsze schematy argumentacji służyły mu jedynie za rodzaj uzupełnienia wcześniejszych myśli.

Kolejnym istotnym elementem argumentacji Jana Gramatyka jest dokonanie zauważalnego $\mathrm{w}$ jego traktacie utożsamienia natury $\mathrm{z}$ substancją $^{51}$. Jest rzeczą bardzo znamienną, że czytając poszczególne argumenty Filopona, wręcz rzuca się w oczy pozorna nieobecność terminu ,substancja". Nie oznacza to jednak, że filozof z tej kategorii nie korzysta. Czyni to, ale w kontekście posługiwania się pojęciem „natura”. To utożsamienie sprawiło, że w jego opinii doktryna chalcedońska głosiła sprzeczność w samą w sobie. Według rozwiązania przyjętego w 451 roku bowiem w Jezusie Chrystusie doszło do zjednoczenia natur w jednej hipostazie, a więc substancji. Skoro Filopon przyjmował tożsamość natury i substancji, dla niego

49 Zob. Joannes Philoponus, Arbiter sive de unione 13, Lang, s. 184.

50 Piąty oraz szósty argument składają się zaledwie z jednego paragrafu.

51 Zob. R.Y. Ebied - A. van Roey - L.R. Wickham, Peter of Callinicum: AntiTritheist Dossier, Leuven 1981, s. 25-26. Por. Joannes Philoponus, On Aristotle Physics 2, ed. A.R. Lacey, New Delhi 1993, s. 26. 
oznaczałoby to przyjęcie konieczności podstawienia tych samych terminów po obu stronach równania, co oczywiście w sposób oczywisty jawiło mu się jako absurdalne.

\section{Podsumowanie}

Celem niniejszej pracy była próba prezentacji filozoficznego schematu argumentacji użytego przez Jana Gramatyka w jego reprezentatywnym dziele Rozjemca dla obrony monofizytyzmu. Osiągnięcie celu pracy było możliwe dzięki analizie wykorzystanych przez Filopona argumentów w najważniejszej części jego traktatu. Materiałem źródłowym niniejszych analiz było sześć pierwszych rozdziałów wspomnianego utworu, w których zawarty jest systematyczny wykład filozofa odnośnie do tej problematyki. Całość pracy została ustrukturyzowana w trzech głównych częściach. Najpierw przybliżono charakterystykę analizowanego utworu. W kolejnej, objętościowo największej, części pracy skupiono się na analizie wykorzystanych przez Jana Gramatyka argumentów broniących doktryny monofizyckiej. Wreszcie w części trzeciej wskazano na najważniejsze cechy argumentacji Filopona.

W świetle przeprowadzonych analiz można stwierdzić, że istotnym aksjomatem wykorzystywanych przez Filopona argumentów jest przyjęcie utożsamienia pojęć „,natura” oraz „substancja” do tego stopnia, że w traktacie filozofa nierzadko są one przedstawiane obok siebie jako synonimy. Co więcej, charakterystyczną cechą metodologii Rozjemcy jest posługiwanie się różnymi przykładami mającymi pokazywać brak koherencji pomiędzy wnioskiem wynikającym z przedstawionego obrazu a doktryną chalcedońską. Dodatkowo warto również zwrócić uwagę na sukcesywność argumentacji Jana Gramatyka, która wyraża się w ścisłej łączności poszczególnych jego argumentów oraz w budowaniu kolejnych schematów dowodzeniowych na poprzednio wyciągniętych wnioskach.

\section{The Philosophical Apology of Monophysitism in John the Grammarian's Arbiter}

(summary)

The main purpose of the paper is an attempt of presentation of philosophical argumentation used by ancient philosopher John Philoponus for justifying the condemned by Council of Chalcedon monophysical doctrine. The purpose realization was possible thanks to analysis of arguments used by Philoponus which arguments were presented in six chapters 
of his Arbiter. The paper was divided into three parts. In the first one the profile of Arbiter was presented. In the second one, which was longer in relation to volume, the philosopher's systematic teaching was analyzed. In the last one the most important features of Philoponus' argumentation were presented. On the basis of the analysis it could be claimed that John Philoponus used the terms "nature" and "substance" interchangeably. What's more, he used different examples for showing the legitimacy of his reasoning and he also builds next arguments on the ground of beforehand conclusions.

Keywords: Philoponus; Arbiter; monophysitism; doctrinal debates; nature

\section{Filozoficzna apologia monofizytyzmu w Rozjemcy Jana Gramatyka}

(streszczenie)

Celem niniejszego opracowania jest próba przedstawienia filozoficznej argumentacji wykorzystanej przez starożytnego filozofa Filopona do uzasadnienia potępionej na soborze chalcedońskim doktryny monofizyckiej. Osiągnięcie celu pracy jest możliwe dzięki przebadaniu użytych przez Jana Gramatyka argumentów w sześciu rozdziałach traktatu Rozjemca. Opracowanie składa się z trzech części. Najpierw ma miejsce krótka charakterystyka analizowanego utworu. Następnie w objętościowo największej części pracy zostaje przeanalizowany systematyczny wykład filozofa pod kątem postawionego problemu badawczego. Wreszcie w części trzeciej wskazano na najważniejsze cechy argumentacji Jana Gramatyka. W świetle przeprowadzonych zestawień można zauważyć wyraźną tendencję Filopona do zamiennego stosowania takich pojęć, jak natura i substancja. Co więcej, autor traktatu chętnie sięga po różne przykłady mające wykazać zasadność jego rozumowania oraz wyraźnie buduje kolejne argumenty na podstawie uprzednio wyciągniętych wniosków.

Słowa kluczowe: Filopon; Rozjemca; monofizytyzm; spory doktrynalne; natura

\section{Bibliografia}

\section{Źródła}

Joannes Philoponus, Arbiter sive de unione, w: John Philoponus and the Controversies over Chalcedon in the Sixth Century: A Study and Translation of the Arbiter, ed. U.M. Lang, Leuven 2001, s. 173-217.

\section{Opracowania}

Bralewski S., Sobór w Chalcedonie w polityce wewnętrznej cesarza Marcjana, „Acta Universitatis Lodziensis. Folia Historica" 44 (1992) s. 53-74.

Cumin P., Christ at the Crux: The Mediation of God and Creation in Christological Perspective, Eugene 2014. 
Ebied R.Y. - Roey A. van - Wickham L.R., Peter of Callinicum: Anti-Tritheist Dossier, Leuven 1981.

Grillmeier A. - Hainthaler T., Christ in Christian Tradition, t. 2, Oxford 2013.

Kosiński R., Dzieje Nestoriusza,biskupa konstantynopola w latach 428-431, „U schyłku starożytności. Studia Źródłoznawcze" 7 (2008) s. 30-63.

Lang U.M., John Philoponus and the Controversies over Chalcedon in the Sixth Century: A Study and Translation of the Arbiter, Leuven 2001.

Lang U.M., Nicetas Chroniates, a Neglected Witness to the Greek Text of John Philoponus' Arbiter, JOTS 48/2 (1997) s. 540-548.

McKenna J.E., The Setting in Life for The Arbiter of John Philoponos, Sixth Century Alexandrian Scientist, Eugene 1997.

Merry B., Encyclopedia of Modern Greek Literature, London 2004.

Nicetae Choniatae ex libro IX thesauri orthodoxae fidei, PG 140, 37-68.

Philoponus, On Aristotle Physics 2, ed. A.R. Lacey, New Delhi 1993.

Philoponus, On Aristotle Physics 3, ed. M.J. Edwards, New Delhi 1994.

Plott J.C., Global History of Philosophy, t. 3, Delhi 1980.

Rigolio A., Christians in Conversation: A Guide to Late Antique Dialogues in Greek and Syriac, Oxford 2019.

Shayegan Y., The transmission of Greek philosophy to the Islamic world, w: History of Islamic Philosophy, red. S.H. Nasr - O. Leaman, London 1996, s. 89-104.

Sielużycki P., Chrystologia Nestoriusza w rozwoju badań ubiegłego wieku, „Salvatoris Mater" 3/4 (2001) s. 151-158.

Sorabji R., Philoponus John, w: The Oxford Classical Dictionary, red. S. Hornblower A. Spawforth, Oxford 2012, s. 1135.

Watts E.J., City and School in Late Antique Athens and Alexandria, Berkeley 2006.

Wildberg Ch., Philoponus, w: Routledge Encyclopedia of Philosophy, red. E. Craig, London 1998, s. 371-378. 